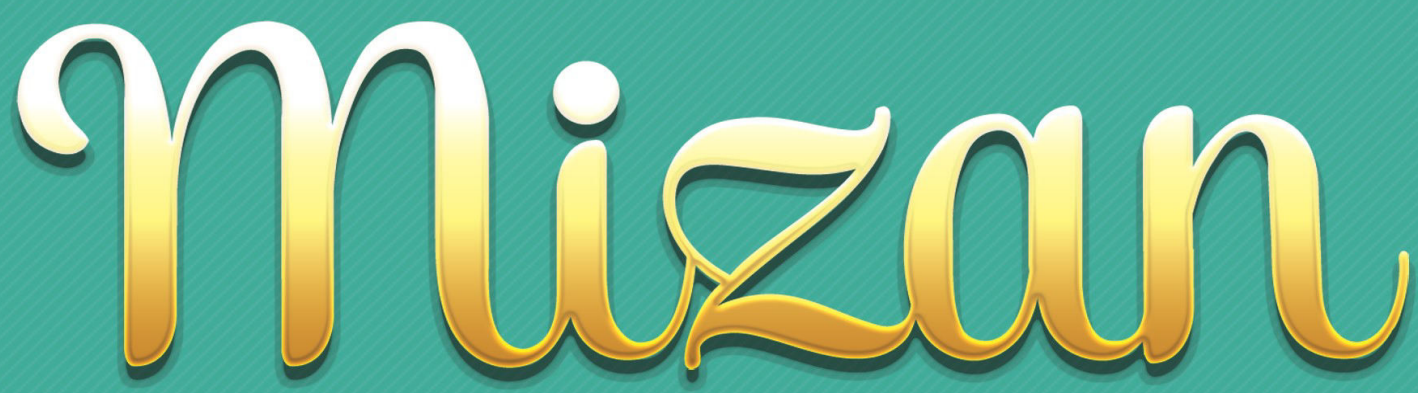

JOURNAL OF ISLAMIC LAW

Diskursus Gender Dalam Hukum Islam Mesraini

Studi Komparatif Antara Hukum Islam dan Hukum Perdata Belanda (BW)

Tentang Wali Nikah Bagi Anak Angkat

Rizky Nanda, Syarifah Gustiawati Mukri

Selisik Upaya Pencegahan Korupsi dan Gratifikasi

Di Kota Tangerang Selatan Banten

Supriyadi Ahmad, Yuniati Nuraini

Studi Komparatif Pemikiran Imam Nawawi dan Yusuf al-Qardhawi

Tentang Berjabat Tangan Dengan Bukan Mahram Dalam Islam

Dani Ahmad Ramdani, Sutisna

Ilhaq Hukum Pada Masyarakat Multi Kultur Indonesia;

Pemikiran Hukum Muhammad Hasyim Asy'ari 1871-1947 M

Qosim Arsadani AS

Makna Fii Sabilillah Sebagai Mustahiq Zakat

Perspektif Sayyid Abu Bakar Asy-Syatho dan Yusuf Qardhawi

Muhammad Hafizhuddin Hazazi, Suyud Arif, Sutisna

Transaksi Tanpa ljab Kabul

Dalam Masyarakat Perspektif Hukum Islam

Ahmad Mukri Aji

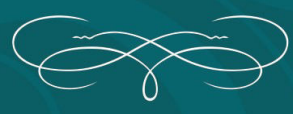

Fakultas Agama Islam

Universitas Ibn Khaldun

Bogor 


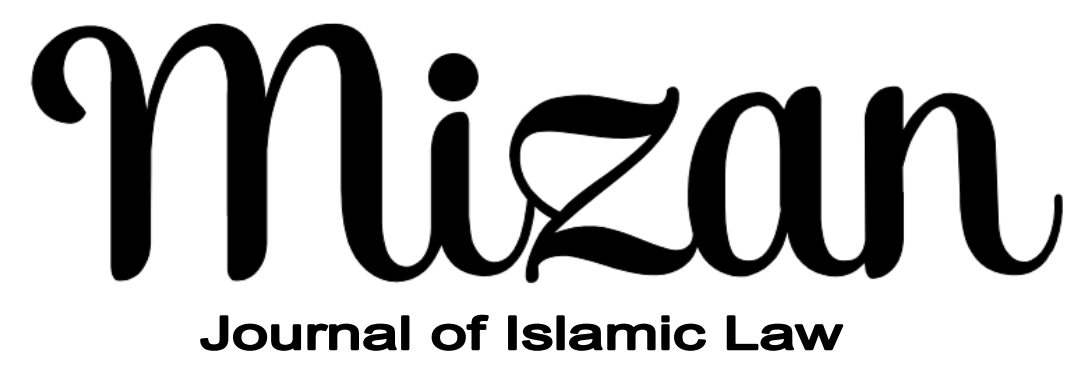

\section{VOL. 2 NO. 1 (2018)}

Mizan: Journal of Islamic Law is continuation of Mizan Ahwal Al-Syakhsiyah Journal since 2013, published by the faculty of Islamic Studies, Universitas Ibn Khaldun (UIKA) Bogor West Java, Indonesia. Mizan of Islamic Law published twice a year since 2017 (June and Desember), is a multilingual (Bahasa Indonesia, Arabic, English, and

Russian), Peer-Reviewed journal, and specialized in Islamic Law, Islamic Studies, and Sharia. This journal is published by the faculty of Islamic Studies, Universitas Ibn Khaldun Bogor, in partnership with APSI (Indonesian Sharia Advocates Association). Editors welcome scholars researchers and pratitioner of Islamic Law around the world to submit scholarly articles to be published throught this journal. All articles will be reviewed by experts before accepted for publication, each author is solely responsible for the content of published articles.

MIZAN; Journal of Islamic Law has been indexed at Google Scholar, Moraref, Sinta, and become a CrossRef Member since year 2017. Therefore, all articles published by MIZAN; Journal of Islamic Law will have unique DOI number.

[ISSN: 2598-974X, E-ISSN: 2598-6252]

\section{ADVISORY EDITORIAL BOARD}

Didin Hafidhuddin (Universitas Ibn Khaldun Bogor)

Muhammad Munir (International Islamic University Islamabad, Pakistan)

Andi Salman Maggalatung (UIN Syarif Hidayatullah Jakarta)

Ending Bahruddin (Universitas Ibn Khaldun Bogor)

Ahmad Mukri Aji (UIN Syarif Hidayatullah Jakarta)

Muhammad Kholil Nawawi (Universitas Ibn Khaldun Bogor)

Hendri Tanjung (Universitas Ibn Khaldun Bogor)

Irfan Syauqi Beik (Institut Pertanian Bogor)

Nur Rohim Y (Kazan Federal University, KFU Russia)

\section{EDITOR IN CHIEF}

Syarifah Gustiawati Mukri

$$
\begin{gathered}
\text { EDITORS } \\
\text { Suyud Arif } \\
\text { Sutisna } \\
\text { Yono }
\end{gathered}
$$

\section{ASSISTANT TO THE EDITORS}

Siti Anisaul Kamilah

\section{Redaktur Office}

Fakultas Agama Islam Universitas Ibn Khaldun Bogor Jawa Barat

Jl. KH. Sholeh Iskandar KM. 2 Kedung Badang Tanah Sareal Bogor 16162

Telp. (62-251) 8356884, Faks. (62-251) 8356884

Website: http://www.jurnalfai-uikabogor.org/index.php/mizan,

E-mail: jurnalmizan.uikabogor@gmail.com

Permalink: https://uika-bogor.academia.edu/JurnalMizanUIKABogor 


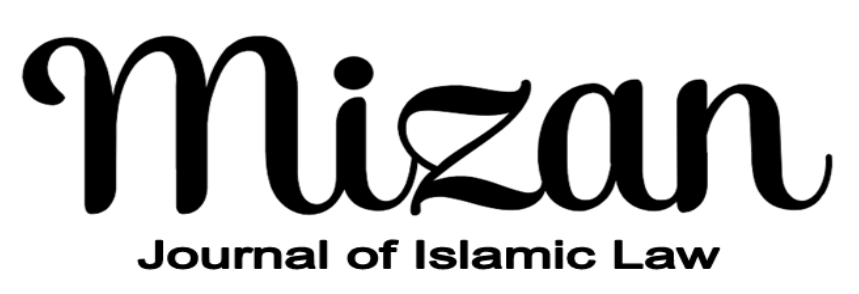

Menyambut baik kontribusi dari para ilmuwan, sarjana, profesional, dan peneliti dalam disiplin ilmu hukum untuk dipublikasi dan disebarluaskan setelah melalui mekanisme seleksi naskah, telaah mitra bebestari, dan proses penyuntingan yang ketat. 


\section{DAFTAR ISI}

1 Diskursus Gender Dalam Hukum Islam

(Gender Discourse in Islamic Law)

Mesraini

13 Studi Komparatif Antara Hukum Islam dan Hukum Perdata Belanda (BW) Tentang Wali Nikah Bagi Anak Angkat

(Comparative StudyBetween Islamic Law and Dutch Civil Law (BW) About Marriage Guardians for Adopted Children)

Rizky Nanda, Syarifah Gustiawati Mukri

29 Selisik Upaya Pencegahan Korupsi dan Gratifikasi Di Kota Tangerang Selatan Banten

(Efforts to Prevent Corruption and Gratification in South Tangerang City of Banten) Supriyadi Ahmad, Yuniati Nuraini

47 Studi Komparatif Pemikiran Imam Nawawi dan Yusuf al-Qardhawi Tentang Berjabat Tangan Dengan Bukan Mahram Dalam Islam

(Comparative Study of Imam Nawawi and Yusuf al-Qardhawi about Shaking Hands Not Mahram in Islam)

Dani Ahmad Ramdani, Sutisna

59 Ilhaq Hukum Pada Masyarakat Multi Kultur Indonesia; Pemikiran Hukum Muhammad Hasyim Asy'ari 1871-1947 M

(Ilhaq Law in Multi Culture Society of Indonesia; Legal Thought Muhammad Hasyim Asy'ari 1871-1947)

Qosim Arsadani AS

75 Makna Fii Sabilillah Sebagai Mustahiq Zakat Perspektif Sayyid Abu Bakar Asy-Syatho dan Yusuf Qardhawi

(The Meaning of Fi Sabilillah As Mustahiq Zakat Perspective Sayyid Abu Bakar AsySyatho and Yusuf Qardhawi)

Muhammad Hafizhuddin Hazazi, Suyud Arif, Sutisna

91 Transaksi Tanpa Ijab Kabul Dalam Masyarakat Perspektif Hukum Islam

(Unsolicited-Qabul Transaction in Society Perspective of Islamic Law)

Ahmad Mukri Aji 



\title{
Transaksi Tanpa ljab Kabul Dalam Masyarakat Perspektif Hukum Islam ${ }^{\star}$ \\ (Unsolicited-Qabul Transaction in Society Perspective of Islamic Law)
}

\author{
Ahmad Mukri Aji \\ Universitas Islam Negeri Syarif Hidayatullah Jakarta \\ Jl. Ir. H. Juanda No. 95 Ciputat Tangsel \\ E-mail: mukri.aji@uinjkt.ac.id
}

DOI: https://doi.org/10.32507/mizan.v2i1.215

\begin{abstract}
:
Buying and selling as a suggestion for help between humans has a strong foundation in the Koran and the sunnah of the Prophet Muhammad. There are so many verses of the Koran that talk about buying and selling, one of which is Surat al-Baqarah verse 275. Whereas in the words of the Prophet Muhammad SAW it was seen when asked by one of his friends about what was the best job It turned out that the answer was the effort of the human hand itself and every blessed sale and purchase. But what about when buying and selling transactions without going through qabul, even though he is a legitimate contract in buying and selling. Therefore the author wants to do an analysis in the perspective of Islamic law on this community tradition.
\end{abstract}

Keywords: Transactions, Ijab Kabul, Community Traditions

\begin{abstract}
Abstrak:
Jual beli sebagai saran tolong menolong antara sesama umat manusia mempunyai landasan yang kuat dalam al-Quran dan sunnah Rasulullah SAW. Banyak sekali ayat al-Quran yang berbicara tentang jual beli, salah satunya adalah surat al-Baqarah ayat 275. Sedangkan dalam sabda Rasulullah SAW terlihat ketika ditanya salah seorang sahabat mengenai pekerjaan (profesi) apa yang paling baik. Ternyata jawabanya adalah usaha tangan manusia sendiri dan setiap jual beli yang diberkati. Akan tetapi bagaimana ketika transaksi jual beli tanpa melalui ijab qabul, padahal ia merupakan akad sah dalam jual beli. Oleh karenanya penulis ingin melakukan analisis dalam perspektif hukum Islam akan tradisi masyarakat ini.
\end{abstract}

Kata Kunci: Transaksi, Ijab Kabul, Tradisi Masyarakat

${ }^{*}$ Naskah diterima tanggal: 22 Maret 2018, direvisi: 22 Mei 2018, disetujui untuk terbit: 11 Juni 2018. 


\section{Pendahuluan}

Risalah Islamiyah yang dibawa oleh Nabi Muhammad SAW telah diyakini sebagai ajaran yang universal tidak terbatas dan dibatasi oleh waktu dan tempat tertentu. Isi dan muatan ajarannya mengandung nuansa kasih sayang dan rahmat untuk seluruh lapisan umat manusia di mana pun berada, yang mengantarkan kebahagiaan dan kesuksesan hidup di dunia serta kebahagiaan dan keselamatan hidup di akhirat. ${ }^{1}$

Ajaran yang bersifat universal ini diharapkan dapat merespon seluruh aspek aktifitas kehidupan dan kepentingan manusia di sepanjang zaman yang mengacu kepada sumber ajaran al-Qur'an dan Hadis. ${ }^{2}$ Implementasi dari seluruh aktifitas manusia untuk mencapai tujuan yang didambakannya itu diikat oleh seperangkat aturan-aturan dan norma-norma hukum. Semua itu teraktualitasasi dalam bentuk ayat-ayat hukum dan hadis-hadis hukum, baik yang berkait dengan hubungan vertikal kepada Allah SWT, maupun secara horizontal antara sesama manusia dan lingkungannya. ${ }^{3}$

Ayat-ayat hukum dan hadis hukum yang menjelaskan aturan-aturan ibadah disebut dengan Ahkamul al-Ibadah atau disebut juga dengan fikih ibadah. Sedangkan ayat-ayat hukum dan hadist hukum yang menerangkan aturanaturan atau norma-norma hubungan antar manusia disebut dengan Ahkamul alMua'amalah atau dikenal sebagai fikih Mu'amalah.

Mu'amalah secara harfiah berarti "pergaulan" atau hubungan antara manusia. Dalam pengertian harfiah yang bersifat umum ini, mu'amalah berarti perbuatan atau pergaulan manusia di luar ibadah. Mu'amalah merupakan perbuatan manusia dalam menjalin hubungan atau pergaulan antar sesama manusia, sedang ibadah merupakan hubungan atau "pergaulan manusia dengan Tuhan."

Sebagai istilah khusus dalam hukum Islam, fikih mu'amalah adalah fikih yang mengatur hubungan antar individu dalam sebuah masyarakat. Dengan pengertian yang luas ini, hubungan antar individu yang dikenal dengan bidang perkawinan, waris, dan lain sebagainya, selain ibadah, masuk dalam pengertian mu'amalah. $^{4}$

${ }^{1}$ Lihat: al-Qur'an al-Karim Q.S. 34 (Saba): 28 yang berbunyi: “Dan kami tidak mengutus kamu melainkan kepada umat manusia seluruhnya sebagai pembawa berita dan sebagai pemberi peringatan, tetapi kebanyakan manusia tidak mengetahui". Hal tersebut juga sejalan dengan firman Allah SWT Q.S. 21 (al-Anbiya): 107: "Dan tiadalah kami mengutus kamu, melainkan untuk menjadi (rahmat) bagi semesta alam". Lihat pula: Mahmud Syaltut, al-Islam 'Aqidah wa Syari'ah, (Mesir: Dar al-Qalam, 1972), h. 9.

${ }^{2}$ Abd al-Wahhad Khallaf, I'Im Usul al-Fiqh, (al-Qariah: Dar al-Khaitiyyah, 1942), h.11. lihat pula: 'Abd al-Qadir 'Audah, at-Tasyri al-Jinai al Islami, (Beirut: Muassasah ar-Risalah, 1994), h. 16

${ }^{3}$ Lihat pula: Mahmud Syaltut, al-Islam 'Aqidah wa Syari'ah, h. 12-13

${ }^{4}$ Ghufron A. Mas'adi, Fiqh Mu'amalah Kontekstual, (Jakarta, PT Raja Grafindo Persada, 2002) h.1-2 
Untuk mewujudkan hubungan antar individu dalam berbagai persoalan mu'amalah, harmonis dan sejahtera. Islam melalui fikih mu'amalah, mengikatkan hubungan tersebut dengan akad atau disebut pula dengan transaksi, akad ini bertujuan untuk mengikatkan kedua belah pihak yang saling membutuhkan agar tercipta kepuasan dan kerelaan antara kedua belah pihak. Contoh dari hubungan tersebut adalah pernikahan, jual-beli, 'ariah (pinjam meminjam), al-rahn (penggadaian), dsb. Namun, aplikasi akad pada saat ini banyak terpengaruh dengan kemajuan ilmu pengetahua dan teknologi (Iptek) di berbagai bidang. Misalnya di bidang ekonomi, bisnis, pendidikan, sosial, dsb. Pengaruh kemajuan iptek ini, menyebabkan pergeseran sendi-sendi prinsipil dari akad.

\section{Pengertian Akad}

Kata akad diadopsi dari kata bahasa Arab, yaitu al-'aqd berarti perikatan, perjanjian, dan permufakatan. ${ }^{5}$ Menurut Musthafa al-Zarqa, dalam kitabnya alMadkhal al-Figh al-'amm, mengartikan akad dengan al-rabth: "ikatan atau mengikat." Kemudian beliau mendefinisikannya, yang berisi "al-rabth, yaitu menghimpun atau mengumpulkan dua ujung tali dan mengakibatkan salah satu pada lainnya hingga keduanya bersambung dan menjadi seperti seutas tali yang satu." 6

Dalam terminologi hukum Islam akad didefinisikan sebagai berikut:

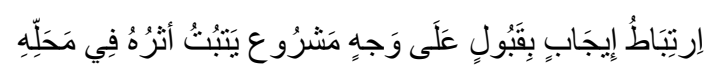

"Akad adalah pertalian antara ijab dan kabul yang dibenarkan oleh syara' yang menimbulkan akibat hukum terhadap objeknya."

Yang dimaksud dengan ijab dalam definisi akad adalah ungkapan atau pernyataan kehendak melakukan perikatan (akad) oleh suatu pihak, yang mengandung keinginannya secara pasti untuk mengikatkan diri, biasanya disebut sebagai pihak pertama. Sedangkan qabul adalah pernyataan atau ungkapan pihak lain yang menunjukkan persetujuannya untuk mengikatkan diri, biasanya dinamakan pihak kedua, menerima atau menyetujui pernyataan ijab. Atas dasar ini, setiap pernyataan pertama yang dikemukakan oleh salah satu pihak yang ingin mengikatkan diri dalam suatu akad disebabkan dengan mujib (pelaku ijab) dan setiap pernyataan kedua yang diungkapkan oleh pihak lain setelah ijab disebut dengan qabil (pelaku kabul); tanpa membedakan antara pihak mana yang memulai pernyataan pertama tersebut. ${ }^{7}$

${ }_{5}$ Ensiklopedia Hukum Islam, (Jakarta: PT. Ichtiar Van Hoeve, 1999) Cet. Ke-3 hlm. 63 Wahbah Zuhaili mengartikan akad sebagai pertalian "pertalian antara dua ujung sesuatu", dalam al-fiqh al-Islami wa Adillatuh, (Beirut: Darul Fikri, 1995), jilid 4., h. 80

${ }^{6}$ Musthafa al-Zarqa, al-Madkhal al-Fiqh al-'amm, (Beirut: Darul Fikri, 1967-1968) jilid I, h. 8

${ }^{7}$ Ensiklopedia Hukum Islam, h. 64 
Misalnya dalam akad jual beli, jika pernyataan untuk melakukan jual beli datangnya dari penjual, maka penjual disebut dengan mujib sedangkan pembeli disebut dengan qabil. Pernyataan ijab tidak selalu datangnya dari pembeli, melainkan boleh juga datangnya dari penjual. Apabila ijab kabul tersebut telah memenuhi syara', maka terjadilah perikatan antara pihak-pihak yang melakukan ijab dan kabul tersebut dan muncullah segala akibat hukum dari akad yang disepakati tersebut. dalam kasus jual beli, akibatnya adalah berpindahnya kepemilikan barang dari penjual kepada pembeli dan penjual berhak menerima harga barang. Ijab dan kabul ini dalam istilah fikih disebut sigah al-'aqd (ungkapan/pernyataan akad).

Maksud term "yang dibenarkan oleh syara' ('ala wajhin masyru'in) adalah bahwasanya setiap akad tidak boleh bertentangan dengan ketentuan syariat Islam. Term ini merupakan batasan yang normatif yang sangat prinsip dalam fikih mu'amalah. ${ }^{8}$ Misalnya, mengkonsumsi narkoba menurut ajaran Islam hukumnya haram, maka segala hal yang terkait dengan produksi dan distribusi narkoba (termasuk akad-akad yang terkait dengannya) juga bertentangan dengan ajaran Islam, karena itu hukumnya adalah haram juga.

Akad seperti yang disampaikan dalam definisi diatas merupakan salah satu perbuatan atau tindakan hukum. artinya akad (transaksi) tersebut menimbulkan konsekuensi hak dan kewajiban yang mengikat pihak-pihak yang terkait langsung maupun tidak langsung dengan akad. Perbuatan atau tindakan hukum atas harta benda dalam fikih mu'amalah dinamakan tasharruf. ${ }^{9}$

\section{Rukun akad dan syaratnya}

Terdapat perbedaan pandangan di kalangn fuqaha berkenaan rukun akad. Menurut jumhur fuqaha' rukun akad terdiri atas:

1. Al-Aqidah, maka akad dalam jual beli terdiri dari pembeli dan penjual

2. Mahal al-Aqd, yakni obyek akad, yaitu sesuatu yang hendak diakadkan

3. Sighat al-'Aqd, yakni pernyataan kalimat akad, yang lazimnya dilaksanakan melalui pernyataan ijab dan kabul. ${ }^{10}$

Ulama Madzhab Hanafi berpendirian bahwa rukun akad itu hanya satu, yakni, sedangkan pihak-pihak yang berakad dan objek akad menurut mereka tidak termasuk rukun akad, tetapi syarat akad. Karena menurut hemat mereka

${ }^{8}$ Ghufron A. Mas'adi, op.cit., h. 77

${ }^{9}$ At-Tasharruf adalah segala (perbuatan) yang bersumber dari kehendak seseorang dan syara' menetapkan atasnya sejumlah akibat hukum (hak dan kewajiban). Ini adalah pengertian yang disampaikan oleh Musthafa al-Zarqa', op.cit,. h.288. Wahbah al-Zuhaily menyampaikan definisi yang hampir serupa, At-Tasharruf adalah segala sesuatu yang bersumber dari kehendak seseorang dan syara' menetapkan sejumlah akibat hukum, op.cit., h.83

${ }_{10}$ Wahbah Zuhaili, op.cit,. h.92 
yang dikatakan rukun itu adalah suatu esensi yang berada dalam akad itu sendiri, sedangkan akad pihak-pihak yang berakad dan objek akad sudah berada diluar esensi akad.

Sigah al-'aqd (formula transaksi) merupakan rukun akad yang terpenting, karena melalui pernyataan inilah diketahui maksud setiap pihak yang melakukan transaksi atau akad. Sigah al-'aqd dapat diwujudkan melalui ijab dan kabul.

Dalam kaitannya dengan ijab dan kabul, Wahbah Zuhaili dalam kitabnya Al-Figh al-Islami wa adillatuh, mensyaratkan:

a. Kejelasan bentuk pernyataan ijab dan kabul, artinya setiap pernyataan ijab dan kabul harus jelas menunjukkan maksud tiap-tiap pelaku akad, sehingga dapat dipahami dari pernyataan itu jenis akad yang dikehendaki, karena akad-akad itu sendiri berbeda dalam sasaran dan hukumnya.

b. Antara ijab dan kabul terdapat kesesuaian, artinya antara pernyataan ijab tidak bertentangan dengan pernyataan kabul.

c. Bersatunya antara ijab dan kabul, artinya ijab dan kabul harus dalam satu situasi dan kondisi.

\section{Pengertian jual beli (bay')}

Al-bay' secara harfiyah berarti menjual, mengganti, dan menukar. Adapun secara istilah, ada beberapa definisi yang dikemukakan ulama fikih. Di kalangan ulama madzhab Hanafi terdapat dua definisi. Pertama saling menukar harta dengan harta melalui cara tertentu". Kedua, tukar menukar sesuatu yang diingini dengan yang sepadan melalui cara tertentu yang bermanfaat.

Definisi lain dikemukakan ulama madzhab Maliki, Syafi'i, dan Hanbali. Menurut mereka, jual beli adalah "saling menukar harta dengan harta dalam bentuk pemindahan milik dan kepemilikan." Karena ada juga tukar menukar harta tersebut sifatnya bukan pemilikan, seperti ijarah (sewa menyewa).

\section{Dasar hukum Jual Beli}

Jual beli sebagai saran tolong menolong antara sesama umat manusia mempunyai landasan yang kuat dalam Al-Qur'an dan sunnah Rasulullah SAW. Banyak sekali ayat Al-Qur'an yang berbicara tentang jual beli, salah satunya adalah surat al-Baqarah ayat 275, yang artinya: "Allah telah menghalalkan jual beli dan mengharamkan riba". Sedangkan dalam sabda Rasulullah SAW, salah satunya adalah hadis dari Rifa'ah bin Rafi' al-Bazzar dan al-Hakim yang menyatakan bahwa Rasulullah pernah bersabda, ketika ditanya salah seorang 
sahabat mengenai pekerjaan (profesi) apa yang paling baik. Rasulullah ketika itu menjawab: "Usaha tangan manusia sendiri dan setiap jual beli yang diberkati". Maknanya adalah jual beli yang jujur, tanpa diiringi kecurangan dan mendapat berkat dari Allah SWT.

Dari kandungan ayat al-Quran dan hadis di atas, ulama fikih menyatakan bahwa hukum asal dari jual beli adalah muah (boleh).

\section{a. Rukun dan syarat}

Dalam menentukan rukun jual beli ini terdapat pula perbedaan pendapat, seperti halnya masalah rukun dalam akad. Perbedaan pendapat itu masih ditonjolkan pula oleh ulama madzhab Hanafi dan jumhur ulama. Ulama Hanafiah masih berpendirian bahwa rukun jual beli hanya satu, yakni ijab dan kabul.

Hal ini berbeda dengan pendapat jumhur ulama, yang menyatakan rukun jual beli ada empat, yaitu: (a). Orang yang berakad (penjual dan pembeli), (b). Shigat (ungkapan ijab dan kabul), (c). Ada barang yang dibeli, (d). Ada nilai tukar pengganti barang.

Adapun syarat jual beli sesuai dengan rukun jual beli yang dikemukakan jumhur ulama, adalah sebagai berikut:

1. Syarat orang yang berakad, diantara syarat ini adalah:

a. Berakal. Oleh sebab itu, jual beli yang dilakukan dengan anak kecil yang belum berakal dan orang gila hukumya tidak sah.

b. Yang melakukan akad itu orang yang berbeda. Artinya seseorang tidak dapat bertindak dalam waktu yang bersamaan sebagai penjual sekaligus pembeli.

2. Syarat yang terkait dengan ijab kabul. Menurut jumhur ulama, syaratsyarat itu yaitu:

a. Orang yang mengucapkan telah akil, baligh, dan berakal

b. Kabul sesuai dengan ijab

c. Ijab dan kabul itu dilakukan dalam satu majelis

3. Syarat barang yang diperjual belikan, adalah sebagai berikut:

a. Barang itu ada, atau tidak ada di tempat tetapi pihak penjual menyatakan kesanggupannya untuk mengadakan barang itu.

b. Dapat dimanfaatkan dan bermanfaat bagi manusia.

c. Milik seseorang

d. Bisa diserahkan saat akad berlangsung, atau pada waktu disepakati bersama ketika transaksi berlangsung. 
4. Syarat nilai tukar (harga barang), yaitu:

a. Harga yang disepakati kedua belah pihak harus jelas jumlahnya

b. Bisa diserahkan pada waktu akad.

\section{Pokok-Pokok Masalah}

Setelah dijelaskan secara global landasan teoritis dari akad/transaksi, kami ingin mengajak para diskusan untuk memberikan pandangan terhadap fenomena yang terjadi di tengah-tengah masyarakat, khususnya masalah jual beli yang aktual saat ini. Proses dan cara bertransaksi khususnya jual beli pada saat ini mengalami kemajuan yang pesat.

Di daerah perkotaan misalnya Jakarta, Bogor, Bekasi, dan sekitarnya kita sering menemukan tempat-tempat belanja yang sudah memakai sistem jual beli mutakhir, managemennya pun sudah mengikuti perkembangan zaman. Misalnya tempat perbelanjaan hypermarket contoh Carrefour di Lebak Bulus, Supermarket, contohnya Tip Top di Ciputat, Minimarket, contohnya AA Swalayan di Parung, dan lain sebagainya.

Di tempat-tempat perbelanjaan yang berbau market tersebut, contohnya di Mini market AA Swalayan Parung-Bogor seorang pembeli yang berbelanja di tempat tersebut diberikan khiyar ${ }^{11}$ untuk memilih dan menentukan barangbarang yang ia kehendaki dan sesuai dengan kebutuhannya. Ia tidak perlu lagu memutar otak bahkan mengeluarkan jurus-jurus rayuan untuk mengkompromikan harga barang. Di tempat tersebut tiap-tiap al-maby' yaitu objek barang yang di jual, sudah memiliki harga tetap sehingga tidak ada lagi proses tawar menawar barang. Harga tetap tersebut dapat dilihat dari bandrol barang-barang tersebut.

Ketika pembeli tersebut sudah merasa sesuai dengan barang-barang yang dihajatkannya, kemudian dia menyerahkannya ke penjual yang diwakilkan oleh para pramuniaga di tempat kasir. Petugas kasir kemudian menghitung jumlah harga barang yang harus dibayar pembeli. Setelah petugas kasir menghitung dengan rapi dan transparan dan pembeli sudah mengetahui harga yang harus dibayarkan lalu tanpa mengucapkan sepatah dua patah kata ia membayarkannya. Kemudian keluarlah bukti pembayaran yang berupa struk pembayaran.

Fenomena tersebut benar-benar terjadi di tengah-tengah masyarakat kita, bahkan kita pun pernah bahkan sering berbelanja dengan cara tersebut. Dengan cara tersebut, kita tidak menemukan dengan jelas rukun terpenting dari proses transaksi/akad, yaitu shigat al- aqd yang berupa ijab kabul. Sedangkan kita

${ }^{11}$ Hak pilih untuk meneruskan atau membatalkan jual beli 
mengetahui bersama bahwa rukun merupakan suatu hal yang apabila tidak dijalankan, maka hukum perbuatan kita tidak sah. Begitupun halnya dengan shigat al-aqd, yang pada esensinya merupakan rukun dari akad jual beli. Maka apabila kita tidak mengucapkan shigat al-aqd maka hukum jual beli yang kita laksanakan tidak sah. Walaupun demikian ketidakabsahan jual beli tersebut masih diperselisihkan oleh para ulama fikih.

\section{Analisis dan Pembahasan}

Dalam kasus akad jual beli diatas, para ulama masih berbeda pandangan tentang akad jual beli tanpa ungapan ijab dan kabul, yang kemudian para ulama fikih menamakannya dengan bai' al-mua'atah atau at-ta'athi atau al-murawadhohn ${ }^{12}$

Untuk menentukan keabsahan jual beli tanpa ijab kabul ini terdapat perbedaan pendapat di kalangan ulama fikih. Jumhur ulama berpendapat bahwa jual beli seperti ini hukumnya boleh, apabila hal tersebut sudah merupakan kebiasaan suatu masyarakat di suatu negeri; karena hal itu telah menunjukkan unsur ridha dari kedua belah pihak. Menurut mereka, diantara unsur terpenting dalam transaksi jual beli adalah suka sama suka (at-taradi), sesuai dengan kandungan surat an-Nisa' ayat 29, Allah SWT berfirman: “... Kecuali dengan jalan perniagaan yang berlaku dengan jalan suka sama-suka diantara kamu...."

Perilaku mengambil barang dan membayar harga barang oleh pembeli, menurut mereka, telah menunjukan ijab dan kabul dan telah mengandung unsur kerelaan. Akan tetapi, Ulama Madzhab Syafi'i berpendapat, transaksi jual beli harus dilakukan dengan ucapan yang jelas atau sindiran, yaitu dengan kalimat ijab dan kabul. Oleh sebab itu, menurut mereka, bay' al-mua'atah hukumnya tidak sah, baik jual beli tersebut dalam partai besar maupun dalam partai kecil. Alasan mereka, adalah unsur utama jual beli adalah kerelaan kedua belah pihak. Unsur kerelaan menurut mereka, adalah masalah yang amat tersembunyi di dalam hati. Karena itu kerelaan perlu diungkapkan dengan kata-kata ijab dan kabul, apalagi persengketaan dalam jual beli bisa terjadi dan berlanjut ke pengadilan.

Namun demikian, sebagian ulama Madzhab Syafi'i generasi belakangan seperti Imam an-Nawawi dan al-Bagawi menyatakan bahwa jual beli al-mu'atah tersebut dengan sah, apabila sudah merupakan kebiasaan suatu masyarakat di daerah tertentu. Sebagian ulama Madzhab Syafi'i lainnya membedakan antara jual beli dalam partai besar dan partai kecil. Menurut mereka, apabila yang diperjualbelikan itu dalam partai besar, maka jual beli al-mu'atah tidak sah, tetapi apabila jual beli itu dalam partai kecil, maka jual beli al-mu'atah hukumnya sah.

12 Wahbah Zuhaili mengartikan al-mu'atah sebagai transaksi yaitu dengan saling memberikan reaksi berupa perbuatan atau tingah laku yang menunjukan kerelaan antar kedua belah pihak tanpa melafazkan dengan ijab dan kabul, op.cit., h.99. 
Terkait dengan masala hijab dan kabul ini adalah jual beli melalui perantara, baik melalui orang yang diutus maupun melalui media tertentu, seperti surat menyurat, telepon, facsimile, internet. Ulama fikih sepakat menyepakati bahwa jual beli melalui perantara baik dengan mengutus seseorang atau melalui perantara baik dengan mengutus seseorang atau melalui media tertentu adalah sah, apabila antara ijab dan kabul sejalan. Oleh sebab itu, sekalipun dalam fikih klasik belum di temui pembahasan tersebut, ulama fikih kontemporer, Musthafa Ahmad az-Zarqa dan Wahbah az-Zuhaili (guru besar fikih islam di Universitas Damaskus, Suriah), mengatakan bahwa jual beli melalui perantara tersebut dibolehkan. Menurut mereka, satu situasi dan satu kondisi, sekalipun diantara keduanya berjauhan, tepati topic yang dibicarakan adalah jual beli tersebut.

\section{Kesimpulan}

Setelah dibahas secara cermat tentang transaksi atau akad tanpa ijab kabul di kalangan masyarakat, pemakalah setelah mempelajari berbagai literature yang ada, menyimpulkan bahwa kasus akad tanpa pernyataan ijab dan kabul yang terjadi di tengah-tengah masyarakat memang ada, yaitu shigat al-'aqd yang berbentuk perkataan atau ucapan saja. Karena pada hakekatnya bentuk pernyataan ijab kabul bukan hanya melalui perkataan saja akan tetapi pernyataan tersebut dapat berbentuk tulisan, perbuatan, dan isyarat. Pembagian bentuk pernyataan ijab kabul ini didukung pula oleh tulisan Wahbah Zuhaili. ${ }^{13}$

Dari berbagai penjelasan diatas, dapat ditarik garis besar dari kasus ini bahwa transaksi atau akad dengan ijab kabul masih sesuai dengan zaman bahkan sangat dibutuhkan perwujudannya, karena dengan ada pernyataan ijab kabul pihak yang melakukan transaksi tersebut sudah menimbulkan akibat hukum diantara mereka, yaitu hak dan kewajiban. Si pembeli berhak mendapatkan barang yang diinginkan dan berkewajiban membayar harga barangnya dengan imbalan setimpal. Begitupula dengan si penjual, ia berhak mendapatkan imbalan dan berkewajiban memberikan barang yang diinginkan pembeli sesuai dengan koridor-koridor yang telah ditentukan.

\section{Daftar Pustaka}

Syaltut, Mahmud, al-Islam 'Aqidah wa Syari’ah, Mesir: Dar al-Qalam, 1972

Khallaf, Abd al-Wahhad, I'Im Usul al-Figh, al-Qariah; Dar al-Kwaitiyyah, 1942

'Audah', 'Abd al-Qadir, at-Tasyri al-Jinai al Islami, Beirut: Muassasah ar-Risalah, 1994

13 Wahbah Zuhaili membagi bentuk pernyataan akad menjadi 4 macam, yaitu ucapan, perbuatan, isyarat, dan tulisan. Op.cit., h. 97-103 
Ghufron A. Mas'adi, Drs. MA., Fiqh Mu'amalah Kontekstual, Jakarta, PT Raja Grafindo Persada, 2002

Ensiklopedia Hukum Islam, Jakarta: PT. Ichtiar Van Hoeve, 1999, Cet. Ke-3

Al-Zarqa, Musthafa, Al-Madkhal al-Figh al-'amm, Beirut: Darul Fikri, 1967-1968

Zuhaili, Wahbah, Al-figh al-Islami wa Adillatuh, Beirut: Darul Fikri, 1995, jilid 4... 


\section{Mizan}

MIZAN; JURNAL ILMU SYARIAH (ISSN: 2089-032X) adalah berkala ilmiah yang diterbitkan oleh Program Studi Akhwal al Syakhsyiyyah, Fakultas Agama Islam Universitas Ibn Khaldun Bogor. Mizan; Jurnal IImu Syariah mengkhususkan diri dalam pengkajian ilmu-ilmu Syariah, Hukum Keluarga dan Studi Islam. Terbit dua kali dalam satu tahun di setiap bulan Juni dan Desember.

Redaksi menerima artikel-artikel dari para sarjana, pemerhati, dan peneliti dalam bidang IImu Syariah untuk dipublikasikan setelah proses seleksi yang ketat, telaah mitra bestari, serta proses penyuntingan secara serius. Secara substantif, setiap artikel yang dipublikasikan dalam berkala ilmiah ini merupakan pandangan dan sekaligus akan dipertanggungjawabkan secara ilmiah oleh para penulisnya.

ARTIKEL-ARTIKEL MIZAN; JURNAL ILMU SYARIAH TELAH TERINDEKS DAN ONLINE PADA:

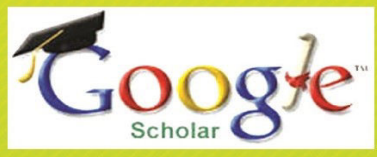

